\title{
Capital or the Capitol?: The Hunger Games Fandom and Neoliberal Populism
}

\author{
Rebecca Hill
}

Populism has become a standard explanation for Donald Trump's surprising electoral-college victory in the 2016 U.S. presidential election. ${ }^{1}$ To the annoyance of left political activists, liberals compared Trump's presidential campaign to that of U.S. Senator Bernie Sanders because of their criticisms of party establishments. Such equivalencies neglect the differences between right and left populisms but capture something important: individuals' political ideas, much less political coalitions, rarely express neat ideological cohesion. ${ }^{2}$ This essay explores how the diverging populisms so visible in the 2016 campaign season converged in an unlikely spot: responses to the popular young-adult (YA) dystopian fiction trilogy The Hunger Games (THG) by Suzanne Collins. Using techniques drawn from Janice Radway's classic study Reading the Romance and from scholars of utopian studies, I interviewed THG fans and read Internet commentaries on the series to understand how a single political fiction could become a universal allegory for contemporary politics despite a polarized political environment. I argue that "neoliberal populism," a seeming oxymoron, unites fans of this series, despite their many real political disagreements.

Following Radway's lead, I chose the most popular recent dystopian text and sought to understand what fans liked about it. ${ }^{3}$ THG has remained the most popular YA dystopia, based on rankings at Amazon and Goodreads. The first book in the series sold more twenty-seven million copies, and the films rank among the highest ticket sales in U.S. history. ${ }^{4}$ On the social media site 


\section{Rebecca Hill}

Goodreads, $T H G$ surpasses all recent dystopian series, as well as the classics of dystopian literature, including 1984 and Brave New World, in the rankings of "best dystopia." These fans read the book not as escapist fantasy but, as Kenneth Roemer notes about readers of Edward Bellamy's Looking Backward, as an allegory for contemporary politics. Roemer explains that readers "placed Bellamy's ideas and narrative episodes within the contexts of key events in their lives, events that represented crucial paradigm shifts or had become icons of strong beliefs." ${ }^{\prime \prime}$ As utopian studies scholars argue, dystopia and utopia are inherently political genres, imagining new societies or warning about our current ones. Such imagined worlds are especially significant for young readers; as Carrie Hintz and Elaine Ostry argue, they "may be a young person's first encounter with texts that systematically explore collective social organization." $T H G$ 's fandom is not limited to young readers. In an episode of the leftist Intercepted podcast, describing Trump's blending of reality television (TV) with the presidency, host Jeremy Scahill intoned darkly, "we are now all part of Trump's Hunger Games."

Rafaela Baccolini argues that dystopian fiction's "function is to warn readers about the possible outcomes of the present world and entails an extrapolation of key features of contemporary society." $T H G$ extrapolates the following features: class division, metropolitan-periphery division, a sadistic televised reality competition, and state surveillance. The series departs from contemporary conditions by portraying a strong state in control of an extractive economy in an allegory to ancient Rome - thus the society's name, Panem, taken from the Latin phrase panem et circenses (bread and circuses). Series author Collins began as a writer for $\mathrm{TV}$, a medium demanding polysemy to appeal to mass audiences. ${ }^{10}$ Thus, the series is similar to post-9/11 TV and film representations of war and national security that David Holloway describes as "allegory lite." For reasons of "pure capitalist utilitarianism," these texts appeal "simultaneously to multiple audiences, alienating as few customers as possible, while transferring responsibility for any politicizing of films to viewers themselves." 11

$T H G$ 's narrator is sixteen-year-old Katniss Everdeen, who lives in District 12 of the country Panem, a dictatorial state whose power is located in a city known as the Capitol. The Capitol extracts wealth from the districts, keeps them under surveillance, and holds an annual tournament in which two young "tributes," a boy and a girl, chosen by lottery from each district, fight a battle to the death on national TV. The tournament, called the Hunger Games, takes place in an arena appearing like a tropical island, where tributes live until there is only one survivor, much as in the reality TV show Survivor. Because of the conditions, they are as likely to die of starvation or illness as by combat, and they must appeal to patrons in the TV audience to receive gifts of medicine or extra food. ${ }^{12}$ In the first of the three books, Katniss volunteers to go to the tournament in place of her younger sister, Primrose, and is accompanied by the male tribute Peeta. Katniss and Peeta survive the games by pretending to be lovers who would rather commit suicide than fight each other to the death, and they become 
national celebrities - only to be sent back to the games in Catching Fire, the second book, in a kind of Hunger Games all-stars. Catching Fire ends with Katniss joining an underground rebellion while the Capitol takes Peeta hostage. ${ }^{13}$ In the third book, Mockingjay, Katniss becomes the Mockingjay, the symbol of an army of resistance that finally topples the dictatorship. ${ }^{14}$ Also important to the story is the character Gale, Katniss's best friend, hunting partner, and love interest left behind in District 12 to mine coal while Katniss fights on TV.

When the first book came out in 2008, Collins commented that she got the idea for the story while flipping channels between reality TV and coverage of the Iraq War. ${ }^{15}$ She also explained that the books were informed by her experiences as the daughter of a traumatized Vietnam veteran. ${ }^{16}$ When the books moved to the screen in early 2012, filmmakers and actors said $T H G$ expressed the values of Occupy Wall Street. ${ }^{17}$ In Thailand, activists used the three-fingered salute depicted in the films to protest the military government installed by a 2014 coup and distributed free tickets to the third movie. Later, the Thai government banned the film after activists showed up at Mockingjay screenings using the salute and wearing "We Don't Want the Coup" T-shirts. ${ }^{18}$ Progressive fans in the United States have asserted that $T H G$ is a progressive critique of the United States. On social media, and in my interviews with them, liberal, progressive, and left fans delighted in discussing how THG critiqued capitalism, the Republican Party, vacuous media, and/or the U.S. empire. But as critics and commentators soon became aware, "Tea Partiers and libertarians" also read $T H G$ as an expression of their politics, seeing in it a message about big government. ${ }^{19}$ Some critics have explained this phenomenon by arguing that $T H G$ is a fundamentally conservative text. For example, in the Guardian, Ewan Morrison argued that $T H G$ and later YA dystopian blockbusters reveal a "tacit right wing libertarianism." ${ }^{20}$ Stella Morabito, a conservative writer at the Federalist, made a similar case, arguing that only the fog of "political correctness" blinded the left to the way that "big government has been used throughout the ages to accumulate wealth for the powerful, to tax excessively those of lesser means, and then to create a huge class who are utterly dependent upon the likes of President Snow, who ends up justifying his harsh policies as a means to 'peace."'21 Despite much popular commentary about ideological diversity among $T H G$ fans, there are few academic studies of readers of $T H G$. Most of these, such as Nicola Balkind's study for the University of Chicago Press's Fan Phenomena series, emphasize progressive uses of the narrative and highlight the series as an example of Henry Jenkins's arguments about participatory fan cultures. ${ }^{22}$ Most recently, Ben Murnane has analyzed published conservative commentary about the novels and films through the lens of Ayn Rand's right wing dystopian fiction, noting that THG became part of right wing political organizing at the Conservative Political Action Conference (CPAC) of 2013, which featured a fake movie trailer based on the series to inspire young Republican activists. ${ }^{23}$ Given the use of $T H G$ as a metaphor across the left-to-right spectrum, audience readings deserve a more extensive treatment. Understanding how right-wing 


\section{Rebecca Hill}

fans read $T H G$ could be helpful for understanding the rise of Trump, who used populist rhetoric while advocating neoliberal policies in a way that continues to flummox commentators who see neoliberalism and populism as fundamentally incompatible.

Intrigued by conservative fans, I began following $T H G$ commentary on various social media sites. To find answers to questions about how fans connected the series to real-world politics, I interviewed twelve $T H G$ fans of different races, ages, genders, and political ideologies, and my graduate assistants interviewed another nine subjects, asking questions about their political beliefs, their analysis of the series, and their regular news sources. I began these interviews on Labor Day weekend in 2013 at the annual Dragon Con fan convention in Atlanta, and my graduate student assistants interviewed fans at Kennesaw State University, a large public state school twenty-five miles north of Atlanta. ${ }^{24}$ I read fan commentary on Jezebel, Salon, Slate, Tumblr, Buzzfeed, Reddit, Hollywood Reporter, The Blaze, Little Green Footballs, FreeRepublic, Breitbart News, and InfoWars and followed discussions in the YA dystopian book club on Goodreads. I found $T H G$ discussions everywhere, even on the neo-Nazi site Stormfront, where one poster described Katniss Everdeen as a "Hitler figure, a veteran, a reluctant hero, an idealist." ${ }^{25}$ To identify the popular reader responses, I tracked themes common to the most "liked" reader reviews on Goodreads and Amazon.

We asked readers about connections they saw between $T H G$ and real-world politics, what they thought the book's overall message was, what it might be "warning readers about," and what political movement they thought the story might align with. We also asked all readers what news sources they viewed or read to know how their interpretations might be shaped by partisan "interpretive communities. ${ }^{26}$ The reason that one series could be so popular with people on opposite political sides in a polarized media environment is not liberal misreading, as Morabito implies, or as some liberal fans insist, that rightwingers are deliberately misreading the series to ride its coattails to popularity. Rather, $T H G$ 's representation of dystopia and resistance gives a neoliberal twist on the tradition of American nationalist populism, which, in its literary form, the western, maps class conflict into zones of metropolitan power and rural folk resistance. Unlike the contemporary conflicts within science-fiction (SF) fandom over book awards, which pit left and right texts against each other in an intrasubcultural culture war similar to what happened in the punk rock scene in the $1980 \mathrm{~s}, T H G$ series has united fans because of its indistinct populist appeal. ${ }^{27}$

Populism is a non-Marxist politics celebrating the "common people" in conflict with corporations, elites, or banks, often with a nationalist or regional center. It can lean right, emphasizing the race of the common people, excoriating banks in opposition to productive industrial capitalism, and advocating collectivism through race or patriarchal Christianity, or it can lean left, advocating interracial activism and democratic regulation of private capital, inflationary currency, and increase of taxation of the rich for the benefit of the "little guy." 28 
Populist movements often combine elements of left and right, as in the original People's Party of 1892, which first proposed the national income tax, opposed immigration, and had a strong traditional Christian element. ${ }^{29}$ Populism is not consistently anti-capitalist but often seeks the restoration of an imagined democratic past, representing present-day elite rule as the result of a cabalistic takeover of the national government. In popular fiction, this populist narrative commonly appears in the western, through what Henry Nash Smith once called the "vernacular hero," a character central to Alexander Saxton's analysis of white supremacist republicanism. ${ }^{30}$ As historian Geoff Eley argues, contemporary far-right populism is characterized by cynicism, "paranoid and apocalyptic fear," and a sense that "power unfolds and is exercised in a distant place, behind closed doors and opaque glass, by conspiracies of elites who are beholden to no one and simply do not care." 31

$T H G$ fans discuss the series through a discourse I call neoliberal populism. Closer to a "structure of feeling" than a coherent ideology, the neoliberal version of populism combines anti-statism with traditional populism's folk solidarity and hatred of elites. ${ }^{32}$ Formal neoliberal ideology celebrates individual entrepreneurship, private ownership, and competition and opposes state economic intervention, repudiating the welfare state as the "road to serfdom." ${ }^{33}$ Neoliberalism is thus incompatible with populism. However, neoliberal hegemony has reshaped populism so that the politics of the "common man" are directed against what is felt to be the enslaving power of the state rather than banks or corporations. This new variety of populism operates within neoliberalism's internal logic, traceable to the cooptation of populism by Alabama Governor George Wallace's assaults on public sector workers and, later, U.S. President Ronald Reagan's anti-tax regime. ${ }^{34}$ Even as it targets the state, neoliberal populism violates central terms of neoliberal ideology, because like the traditional populist form, it sees the wealthy as morally repulsive and decries inequality as unjust while valuing collective resistance over individual competition.

As a text, $T H G$ is available for an array of readings because it lacks descriptive richness, becoming a screen for readerly projection. In addition, conservatives often speak in populist terms. Consider this comment from the conservative website The Blaze, describing why $T H G$ 's Capitol elite represent the Democratic Party, using terms that echo many liberal critiques of the ultrarich and differing from left discourse primarily because it makes individual gun ownership a key signifier of democratic freedom:

The citizens of Panam are ran by a big government/military, [sic] they have no freedom of speech, they are punished for talking against the government, whipped for hunting, the children are indoctrinated in school only being taught basic reading and math and the rest of the education consisting of how an uprising is wrong and being taught a trade. Not to mention that weapons are against the law, electric fences are 
surrounding each district to keep people from leaving or communicating with other districts to stop any possible organizing of uprisings again, and criminals have their tongues cut out and they are turned into slaves. The main character makes it sound like the majority of people can't afford luxuries like cookies, most products harvested from the districts are sent to the government and capitol citizens.... What exactly are the liberals so proudly claiming about [this] ${ }^{35}$

In cultural studies, we have become accustomed to identifying "resistant readings"; but here a progressive narrative is being read "resistantly" by rightwing readers, who see themselves in a counterhegemonic relationship to a dominant liberal ideology.

Through our interviews, readers revealed shared ideas about power, regardless of their stated partisan identities: 1) that citizens should remain vigilant against creeping state tyranny, 2) that the state is responsible for economic inequality, and 3) that the media is manipulative. Where readers on the right differ from those on the left has to do with the allegorical reading of Collins's district-Capitol division. Panem is a reference to 1) the United States versus third-world colonies, 2) U.S. class divisions, or 3) red states versus government by decadent coastal elites.

\section{The Danger of Creeping Tyranny}

The failure of detailed world building in the series allows readers to creatively interpret much of the book, filling in gaps with their own interpretations, particularly because the fast-paced, first-person narrative does not encourage the reader to reflect, making it easy to skip past what might be crucial details. For example, early in the first novel, the town mayor recites Panem's history. He describes the "disasters . . droughts ... storms . . . fires, and encroaching seas" that engulfed North America, leading to a series of wars that ended with the arrangement of the districts around a "shining city" called the Capitol located in the Rocky Mountains. ${ }^{36}$ In the film version, the interpretive field is wider, because it makes no mention of floods, fires, or storms but instead uses a propaganda film that shows a mushroom cloud.

Most readers could not remember the origins of the government of Panem when asked. The visual spectacle of the mushroom cloud from the movie had taken over-many mentioned nuclear war as a cause of Panem's creation. Readers then filled in the blanks by drawing on other dystopian texts, lessons from school, or what they read in political media. Elizabeth, a young white Kennesaw student, described the process of a slowly building tyranny:

I think it started about slowly, like it always does. One particular political party might have been voted into office and 
then used the control it gained from that to put policies into place which restricted freedoms from the people ... a system like doesn't happen overnight. So freedoms were slowly chipped away, and rights were taken away from the people, which they agreed to make at first because they thought their security was more important than their freedoms. And they felt that maybe the government would be taking care of them so it would be ok.... So they were giving up voluntarily until one day they didn't have anything else to give up, and then they were under Panem, and the system was made ... where basically they had no rights.

Liberals, leftists, and libertarians have all argued since 2001 that democracy is being incrementally lost because of concerns about security. Critics of the USA PATRIOT Act suggested that it was the beginning of American fascism. This argument continued among libertarians, right-wing activists, and some leftists who opposed President Barack Obama's policies, and is now central to representations of President Trump as a fascist, with contemporary commentators warning of a coming Reichstag fire event. At the same time, right-wing activists apply this argument about creeping tyranny to the left, as Trump refers to his opponents in the media and the federal bureaucracy as forming a deepstate liberal conspiracy against an outsider president representing the politically disenfranchised deplorables. The deep state was a term once associated with left critiques of international security apparatus, but among right-wing activists, it now refers to all federal civil service workers in a way that is more in tune with the anti-bureaucracy discourses of Wallace, captured by Trump's popular calls to "drain the swamp." 37

Although most of the people we interviewed made arguments similar to Elizabeth's, Madison, a young African American fan, and Javier, a gay male Latino fan, traced Panem's origins to economic inequality. According to Madison, the important extrapolation was from the segregation of the wealthy from the poor:

There's more or less haves . . . and more or less have-nots. The haves ... build their own kind of walls and shelters and societies around things, and the people that don't have are just trying to get what they have, so they control them by ... you can give 'em jobs, but all the jobs are really to serve them at the end of the day .... and I guess that's just a slow progression of less haves and more have-nots and then eventually it gets to that point where it's just a few people and they tell everybody else what to do and if they don't do it, they have all the power to really control it all. 


\section{Rebecca Hill}

Javier emphasized real-world exploitation by employers, "almost like in real life where we work and we get paid shit and we make the boss millions of dollars to do nothing." Despite these references to economic exploitation, both also described an oppressive welfare state. Javier suggested that the dictatorship emerged because of food scarcity, so the wealthy took matters in hand: "OK well, we're wealthy ... we're gonna take care and all of you provide." His analysis, like Madison's, fits with both left and right discourses criticizing U.S. welfare policies, which fed a neoliberal consensus for welfare reform in the 1990s. In populism's apocalyptic imagination, government support for the poor is the seed of creeping dictatorship.

On the right, the theory of economic dependence on government as a tool of state tyranny is more directly connected to anti-welfare discourse. Kristen, a young white conservative Kennesaw student, when asked what the series might be warning readers about, answered, "I can kind of see it relating to the Democrats . . they want you to be dependent on them which is what the Hunger Games government is like." Contradicting Javier's and Madison's descriptions of people working to enrich the bosses, she argued that tyranny could be prevented if people would work harder:

I think ... the government just slowly gained more and more power and the other districts kind of let them until eventually the government just ... took the rest of the power by force. It just attacked them and, and I feel like basically they couldn't function unless they had the government there with them. ... What would prevent us [from becoming like Panem] would be if people change their mindsets. . . Nowadays, people just want free stuff from the government ... and that is leading to the dependency that happened in the Hunger Games. So, if we keep heading that way, then the government gets to that point. ... They take all the power. So, if people are ... willing to work and come and move away from that dependency, then I think we'd be fine.

Rather than misreading, these readings indicate the hegemonic nature of anti-statist, anti-welfare discourse. Because it makes the conflict not between capital and labor but between the Capitol and the districts, $T H G$ feeds this neoliberal common sense, collapsing forms of what Frederic Jameson refers to as "anti-institutionalism" and redirecting a critique of capitalism into anti-totalitarianism. ${ }^{38}$ The Capitol-district narrative, allegorizing the contemporary United States with the Roman Empire, was easily adapted in "resistant readings" by both libertarians and right-wing populists, who see the story as representing red-state nationalism against the federal government or economic nationalism against an international global order. 
Even as the reference to floods and storms might suggest climate change as the initial cause for the collapse to a left reader, for right-wing readers, a climate-change hoax probably caused the rise of Panem's dictatorship. This hoax theory has become an important conspiracy theory, with the United Nations' Agenda 21 described by Attorney General Jeff Sessions as an ominous plot for a global takeover. On the conservative website Free Republic, GraceG traced Panem's origins to Agenda 21. ${ }^{39}$ Similarly, conspiracy theorist Alex Jones calls $T H G$ "Agenda 21 realized," conflating it with his call for resistance against an imminent dictatorship from the global left. $T H G$ must be either an anti-Agenda 21 manifesto whose author reads his site or "predictive programming," getting audiences ready for the society new world order globalists want to create. ${ }^{40}$ Despite ideological differences, liberal, conservative, and ultraright fans share an anxiety about the slow takeover by a tyrannical government whose true aims are secret and whose benefits turn out to be tools of control.

\section{Inequality, Collective Struggle, and Media Spectacle}

The first $T H G$ book, also titled The Hunger Games, which came out in late 2008, is the product of anti-PATRIOT Act activism and the Great Recession, with an emphasis on economic inequality that makes it different from most other popular YA dystopias. The word hunger in the title refers both to the hunger of contestants in the games and to the constant hunger of the people in Panem's impoverished districts. In the books, Katniss also emphasizes the absence of professional medicine in the districts, in contrast with the advanced medical technologies available in the Capitol. Many readers I spoke with identified with struggles for food and health care. Two young white women at Dragon Con, Lauren and Rachel, were typical of those who see the series as a communitarian critique of neoliberal individualism. When I asked them about what they saw as the most serious problems in the United States and how these related to the books and films, they spoke together, eagerly following up on each other's analysis:

Rachel: An unwillingness to help other people ... [is] the high cost of medical care. . . If we don't care about people being able to take care of themselves then we just keep it high, we don't care about insurance we don't care about anything else. Education, you know if you're rich you just send your kids to private school, it doesn't matter about anybody else, I mean ... when you're unwilling to care about anyone else and-

Lauren: - the gap between rich and poor is widening everywhere and there don't really seem to be any measures to fix that.... So they have this highly moneyed class who are giving themselves million dollar bonuses every year when their 
workers are not able to keep their houses, I feel like that's a big problem that has recurred throughout history.

For these fans, selfishness is the chief characteristic of the age, and they read Collins's descriptions of the Capitol-district divide as a metaphorical representation of neoliberal privatization as cruelty. Similarly, most readers praise Katniss and Gale as characters who demonstrate unselfishness. White teenager Rachel, like many others, saw the resistance movement in $T H G$ as similar to the Occupy movement: "you kinda get that $99 \%$ feel when you read. ... It was really fun to identify with, when the march on Wall St. happened ... the common folk banding together."

Collective struggle and a critique of individualism are central to $T H G$, making the series different from many other contemporary YA dystopias, which champion individual agency against group conformity. In such popular YA books as The Giver, Delirium, and Divergent, and even the conformist society governed by IT in the classic $A$ Wrinkle in Time, dystopia appears through the juxtapositions of gray conformity with individual self-expression through the explosion of color. ${ }^{41}$ In what I call the "gray dystopia," people appear content because they have their material wants provided but find that their individual identities are stifled. $T H G$ reverses this representation by depicting capitalist excess as dystopic, satirizing neoliberal self-making as both phony and selfish through the reality TV narrative. We see the Capitol through Katniss's eyes, and it is like a crueler version of the Emerald City-like Dorothy, when she arrives, she is cleaned, waxed, polished, and plucked.

Each competitor is taught to craft an attractive storyline for TV to get wealthy sponsors. Katniss and Peeta are surrounded by a team of stylists and coaches who design their looks and help them practice gestures and facial expressions, "developing their own brands." Romance, as it is in other dystopian YA fictions, is central to the allegory, but in $T H G$, romantic love is not the goal but the means to the end of survival - because it is what the TV audience wants and is safer to express than political solidarity. Fans I spoke with at Dragon Con all appreciated that the love story was not central to the storyline, comparing $T H G$ positively to such books as Twilight. They connected both to the feminist appeal of a strong woman character not focused on love and to the series' critique of shallow media culture, which they saw as central to the privileged life of people in the United States, in contrast with the people of the global south. These fans identified the United States with the Capitol, referring to "us" as too focused on celebrity gossip and fashion, drawing parallels between characters in the Capitol and Americans in general as privileged and thoughtlessly cruel. Alex, a white male fan in his twenties, said $T H G$ 's ultimate message was "Reality TV will kill us all!": "This is the dark, dystopian future of . . Honey Boo Boo where it's like 'Oh look at these crazy poor people ha ha their lives suck! you know, glad I'm not them.' . . . And the massive . . . divide between the capital and the districts, the rich and poor, you know the class gap has just 
gotten totally outrageous so now the poor are actually killing each other for the entertainment of the rich."

Javier, Rachel, and Lauren also mentioned Honey Boo Boo, a nod to the white working-class representation of District 12's Appalachia. But, since the line between capital and the Capitol is blurred by the Roman Empire analogy, right-wing readers of $T H G$ easily turn this populism against the rich into a critique of the greedy representatives of the state. Thus, on a Goodreads discussion, one fan asked "Is Panem Communist?" Several readers replied "yes." One reader explained, "This book illustrates exactly what happens in communist countries. Those in the government live extravagantly. While the majority are living in misery. The government controls who get what jobs and you are not allowed to rise above your station. Commodities are always scarce because their [sic] is no personal incentive to do more than the minimum. Communism is corrosion, poverty, misery and death all for the common good unless you are in government." ${ }^{42}$

Another Dragon Con attendee, Josh, who identified as liberal, also referred to Panem as the "fascism of the far left," suggesting that its extractive economy must be the product of central economic planning denying people a choice of profession. Thus, even readers explicitly identified as liberal or progressive were unable to resist the state-centered reading of tyranny in the story. Kendall, a young white Kennesaw State University student who also identified as liberal, put it this way when asked what she saw as the larger meaning of the stories: "I feel like it does have a deeper meaning like, we were talking about in our English class, we talked about like government control, and . . that's . . very big in my generation. ... My generation is anti-government, we don't need it."

\section{Geography, Race, and Polarized Populists}

Because Panem renders power geographically in a metropolitan-periphery division, and because the author explicitly referred to the Iraq War as a motivation for its writing, many left readers read $T H G$ as an allegory for the United States as an imperial power. Most common among readers of color, this reading pays careful attention to the inter- and intradistrict racial divisions described in the books. District 12 has three racialized classes. The Seam is the miners' village, where both Gale and Katniss live, and here people are dark with olive skin. The blond merchants live in another part of town, and still another is the home to the occupying peacekeepers from District 2. Katniss describes the "Seam look," which she shares with Gale: "Straight black hair, olive skin, we even have the same gray eyes. But we're not related, at least not closely. Most of the families who work in the mines resemble one another this way. That's why my mother and Prim, with their light hair and blue eyes, always look out of place. They are. My mother's parents were part of a small merchant class that caters to officials." ${ }^{43}$ 
During the first book, Katniss forms an alliance with Rue, from District 11. Through her, we learn that District 11 is a plantation society where workers, whose skin is dark brown, are not allowed to eat the crops they grow and are whipped by overseers. ${ }^{44}$ In book two, Katniss again forms an alliance with tributes from District 11, noting that one, Seeder, looks like she could be related to people from the Seam. Thus, pages of fan art on the Tumblr katnissisoliveskinneddealwithit represent Katniss, Gale, and other characters as third-world revolutionaries. In her discussion of this fan community, Balkind describes how fans of color worked to maintain these images and criticized Hollywood's whitewashing of the story. ${ }^{45}$ They also interpret the rebellion as a third-world uprising against the United States, turning Katniss into an anti-imperialist insurgent. For example, one blogger argued that the reading is beyond advocacy for more diverse casting:

Globally, the Capitol exerts its power from abroad to affect the conditions in the Districts so the people in the Capitol can continue their relatively luxurious lifestyles. Generally speaking, countries of the global North often extend their power to force countries in the Global South (predominantly populated by people of color) to operate under oppressive rules ... (IMF, World Bank, conditionalities tied to loans) ... when you know that Collins was inspired by footage of the war in Iraq, it seems a very obvious metaphor ... Katniss Everdeen . . . could be any one of the many people of color coming out of analogous situations. Every day, we see people standing up to dictatorships and demanding political power-just as characters in the Hunger Games eventually do. ${ }^{46}$

The books also didactically advocate interracial alliances within the districts. Exemplifying the regionalist populism of the trilogy, both Gale and Katniss argue that despite inequality, they and the local merchants are on the same side against the Capitol. The call for cross-racial and cross-class unity on the basis of district solidarity also appears in the conclusion of the romance plot, as Katniss finally chooses the blond merchant, Peeta, as a romantic partner over olive-skinned Gale. When Katniss describes their children, their features combine racial characteristics: a girl with blue eyes and dark hair, a boy with golden curls and gray Seam eyes. In this way, the books support a regional or multicultural nationalist, rather than ethnic nationalism or class-based solidarity. Again, because of thin descriptive passages and fast pace, white readers inclined to see a red-state revolt against the federal government skipped over the racial identities of characters in District 11, igniting an Internet controversy over the casting of black actress Amandla Stenberg as Rue in the first movie. ${ }^{47}$

The movies don't sustain the book's racial lessons. Several fans I interviewed at Dragon Con noted the whitewashing, which they'd read about on Je- 
zebel. While they saw it as a perpetual problem in Hollywood casting, none of the Dragon Con fans thought the race of the central characters was relevant to the interpretation of the story. Only one person we interviewed, a young black Kennesaw student named LB, read Katniss as a nonwhite woman. LB was the only interview subject to see racial identity as important for the interpretation of the story: "in my head [I saw] Katniss to be like Native American ... and I kind of expected most of the capitol to be white because that was how it was in reality that white people always had superiority." LB also said that racism was the most important problem in society and mentioned Black Lives Matter during her interview, suggesting that the suppression of a Black Lives Matter "riot" could lead to a dictatorship like Panem. For her, race mattered to the story because of the alliance of Katniss and District 11, making Katniss a better heroic figure: "I felt like when Katniss rose up for them [District 11] and she put in to light that Rue was still important even though she died, it was as if ... these other people still think that they have white superiority, but minorities are just as important." In the film, District 12, rather than being an olive-skinned future Appalachia, could have come straight from 1933. Other familiar historical references to the 1930s appear as well. In the first reaping scene, police set out wooden tables in the town's central squares, lining children up by sex, and checking their names on a list in a scene that evokes Holocaust films. This cinematic realism is matched by historically evocative representations of District 11 when peacekeepers turn firehoses on black protesters and when a police officer shoots an elderly, nonviolent black man in the head after he raises the three-fingered salute to honor Katniss.

Even as they evoke powerful memories of the Holocaust and anti-black violence, the films represent the Capitol as a multicultural metropolis, with several black characters in positions of power, a key piece of evidence for Morabito in her conservative reading of the film. In the first film, the police who drag Katniss off to wait her initiation as a tribute are black. Later, in almost every pan across the privileged, laughing Capitol audiences, the camera rests on a black face. In the second film, the first time that Peeta and Katniss go to a gala event at the Capitol, they are again surrounded by a multiracial glittering crowd of decadent multicultural elites. Such representations are compatible with readings by conservative fans, who read Katniss, Peeta, and Gale as heartland whites suffering from "liberal fascism." For right-wing fans, visual representations of the Capitol's excess represent cultural elites' decadent sexuality. Conservative fan Guy Kibbee, in comments on the Hollywood Reporter site, noted that the Capitol's population has what he termed "effeminate Euro mannerisms" and must be "liberals for sure." 48 Alex Jones drew a similar message from the filmic representation of the Capitol elite. For this audience, Gale and Katniss spending their time hunting in the woods is a white rural identity marker, and it connects to discourses about gun control as a liberal conspiracy for totalitarian control. ${ }^{49}$ This reading of the novels as the story of a heroic white rural resistance dovetails with white-supremacist narratives of revolution, making them 
appear more mainstream. The film's casting closed off this reading when it cast District 11 characters as black, but also closed off the radical third-worldist reading with the casting of Katniss and Gale. In both cases, fans saw the film's casting as a violation of the books, with white readers infamously tweeting that they weren't as sad when Rue died because she was black. Unlike radical anti-imperialists and white nationalists, most media critics read the geography of Panem as a metaphor for working-class struggle against the rich. Similarly, readers who discussed the series with us talked in general terms about haves and have-nots or, as the filmmakers did in 2012, as a representation of the $99 \%$ versus Wall Street.

\section{Is Resistance Futile? Rebellion to Romance}

$T H G$ 's story of rebellion is similar to the western, or in SF representations, to Star Wars, portraying a popular provincial uprising against an evil imperial state. The space western draws on a framing of American national identity as inherently anti-imperial but displaces settler-indigenous conflict just as traditional westerns do, with rural heroes against Eastern-urban elites. ${ }^{50}$ The third book, and third and fourth films in the series, Mockingjay, makes a similar move of displacing imperial conflict with inter-American class conflict by mixing post-Vietnam references to victimized soldiers and by mapping the story inside the United States. Instead of showing a heroic victory of the rebels against the Capitol, Mockingjay twists the populist narrative to critique militarism by depicting psychological damage to Peeta and Katniss, revealing the leader of the rebellion as evil, and by showing Gale, who is a romantic rebel in the first two books, as increasingly ruthless. This last book has resonated strongly with readers who see an analogy between the district's rebels and contemporary U.S. military veterans.

Janine Spendlove, a U.S. Marine who also writes YA fantasy fiction, presented on Dragon Con's official panel on THG in 2013, comparing the story to her experiences in the military. Like the anti-imperialist readers online, she argued that the United States should be understood as the Capitol, with the districts as analogous to the places where the United States intervenes around the world. At the same time, she compared the tributes from those districts and the army of resistance to U.S. soldiers. A reading of the tributes as like the U.S. military - both pawns and noble heroes paying a high price for U.S. freedomis also found in the most popular review of the series on Amazon, written by a self-described military wife:

This is a story of war. And what it means to be a volunteer and yet still be a pawn. We have an entirely volunteer military now that is spread entirely too thin for the tasks we ask of it. The burden we place upon it is great. And at the end of the day, when the personal war is over for each of them, each is 
left alone to pick up the pieces as best he/she can. For some, like Peeta, it means hanging onto the back of a chair until the voices in his head stop and he's safe to be around again. ... What do you do with people who are trained to kill when they come back home? And what if there's no real home to come back to-if, heaven forbid, the war is fought in your own home? $?^{51}$

Just as these military fans make contradictory comments about military action, so the representation of the resistance in the third book is complicated and ambivalent. The resistance, housed in an underground complex in District 13 , can be read as a utopian space: it provides medicine, education, and entertainment and brings Katniss and Gale into the collective decision making. A simple wedding in the books becomes an occasion for joy. Military veterans read District 13 as analogous to the U.S. military fighting for democracy, while some Marxists have read it as an allegory for democratic revolutionary praxis. However, Alex at Dragon Con arrived at this intriguing reading, perhaps more consistent with the third-world nationalist interpretation:

There is no way this [District 13] is not an analogue for North Korea. not like North Korea as it is, but North Korea as it sees itself right? Like the whole idea of Koreans, Juche, independence. We don't need anybody to run our society, we can run it on our own. The truth is of course they can't. District 13 is a version that can. They have that idea that they are gonna be totally isolationist, we are maintaining our isolation by having a giant battery of nuclear weapons that will scare people and that we have this super hostile relationship with the capitol as being the American analogue, the super decadent wealthy ... America as North Korea portrays us, the exploitive capitalist pigs, you know, living off the suffering of the poor, and all this. I really felt like it was this sympathetic version because we always see North Korea as the villain in the news ... but here's the sort of sympathetic version of that right? Here's the current events situation if they were right if they really were kind of the good guys and we really were the bad guys.

However, the two Mockingjay movies render District 13 more gray and ominous. The book Mockingjay also shifts its discussion of media manipulation to the revolutionary movement. The rebellion's leaders film propaganda videos or "propos" that they will hack into the Capitol's regular programming. Noting Katniss's resistance to acting as the symbolic Mockingjay in these films, readers have seen the resistance becoming a mirror of the society it fights. As Rachel put it, "The Resistance starts making their own propaganda kind of things and 
wanting Katniss to do all the [films] . . . and she's like, 'no a real person would never do this kind of thing.' . . . They still wanted it . . . to project a message to the watcher, so they're kind of using the exact same method, the same tactics to manipulate what reality is for their own purposes."

Worse still, the leader of the rebel army, Alma Coin, is cynical, and Katniss fears being used as a pawn. During the course of the war against the Capitol, Gale advocates killing civilians and eventually designs weapons and strategies that lead to the death of Katniss's sister, Primrose. The series concludes when Katniss kills Coin to prevent her from becoming the new dictator and, rejecting Gale, leaves the resistance government to go live with Peeta in the ruins of District 12 to raise their children.

Most fans see this conclusion as complex and satisfying, because it rejects the adventure tale of good versus evil. They agree with Katniss's rejection of Gale for his violence and favor Peeta. For these readers, the ending affirms that politics is a hopeless game, suggesting in straightforward neoliberal realist terms that, as Margaret Thatcher once put it, "there is no alternative." Populist revolt may be fun in fantasy, but it becomes its own source of horror, ultimately worse than the status quo. Shawn, a white male teacher who identified as a libertarian, reads the series as libertarian because "well, you replace one government with another and that does not necessarily mean it's a good thing. It's all the same thing. Power is power." Taryn, quickly summarizing all efforts to resist, ended the series wondering whether resistance was worth it:

We elect people, and we let them say what ... they say. And we back it without really having much choice in what they are actually doing. If people would exercise their right to vote, they might be able to change it. ... A And then when the time came for them to riot and for them to change, they were all so immediately squashed by the military and it took getting out of there and building their own secret society to slowly be able to even take over that. And even then, who's to say that this was the right decision?

Shawn and Taryn were similar to most fans commenting on Internet forums. When discussing District 13, they drew parallels between the resistance and revolutions in foreign countries. The films also seem to warn against resistance; LB and others worried that a popular uprising or riot would justify the end of formal democracy. Most fans wound up in a similar place, arguing that failure of revolution is the central message of the series. Lauren told me:

I feel like one of the main messages of Hunger Games is ... the cyclical nature of dictatorships ... kind of similar to the Bolshevik Revolution, and then ... the sort of era of Communism that Russia had, they had they were oppressed by 
the Czars and then they overthrew him and then they were oppressed just as badly if not worse under Communism, so ... I think at the end of Mockingjay when they were planning to reinstate the Hunger Games again to ... punish the capitol. ... Katniss ended it because she knew that was just the same thing under a different leader that's why she assassinated President [Coin] . . . so probably it's a simplification that violence breeds more violence and that it doesn't really solve anything.

Whether in interviews or on web discussions, most readers describe the series ending as key to its complexity, refusing both a happy ending and a partisan position. Kira, a white schoolteacher who identifies as progressive, commented:

I did not see it as aligned with any particular party so much as undermining the whole system and the idea that everybody had an agenda. Which is where it comes into, at the endSnow versus Coin, if it had been aligned with one particular party ... Collins would have painted one of them as right. Whereas we see one is just as bad as the other, and when [Katniss] shoots Coin she is trying to undo both systems. And that's one of the things I actually like about it, is ... if it had just aligned with one versus the other, the message wouldn't have been near as important.

While these readers argue that the conclusion is better than other stories because it does not tell a simple adventure story of good guys versus bad guys, it is here that Mockingjay does fit the more conventional anti-utopian narrative pattern described by Jameson, Tom Moylan, and other utopian studies scholars. As in 1984, revolutionaries will become the mirrors of the societies they fight, creating dystopia instead of utopia. In this way, what was set up as a populist narrative fails to shake the pervasive anti-utopianism of neoliberalism that there is no alternative to capitalist realism - and most readers argue that this realism is an important aspect of what elevates $T H G$ from an escapist adventure story into a serious literary and meaningful political text.

Although more than 600,000 Goodreads readers gave Mockingjay five stars, thousands of dissident readers begged to differ. One popular Amazon review of the series is titled simply: "cheated, disappointed and betrayed." 52 Dissident readers complain that the conclusion leaves Katniss whiny instead of heroic so that rather than an ethical warrior, she is just another stereotypical character of YA romance. "Khan (The Grinch)" on Goodreads brought together some of the most common fan criticisms: "What the fuck happened to Katniss?! How did she end up being so admirable and awesome in the first two books and turned into such a sniveling, squishy mess in this one? ... In this book, Gale 
was my favorite. He's the voice of reason. It's war, people have to die in order for there to be peace." ${ }^{53}$

Alex commented that the resolution violated the earlier critique of reality TV that he had found so important: "Honestly ... this whole sort of the fakeness of their [Katniss and Peeta's] relationship I thought was brilliant and that's why I was so mad that they did actually end up getting married in the end. It was a total cop-out ending that must have been demanded by an editor. It was like 'no she's got to marry one of them, it doesn't matter who. Just like make her married at the end, you know fat and happy with lots of babies.' . . . I thought it was total bullshit."

Katniss's marriage to Peeta is the source of the most heated diatribes by angry fans. If we read the romance plot as a political allegory, it's important that Gale, instead of being portrayed as a romantic revolutionary, is an increasingly dangerous man driven by revenge. In the third book, Gale's transformation makes a comment on revolution. As Katherine R. Broad puts it, "the novels present Gale as the necessary but ultimately undesirable underside of revolutionary politics" and "set up" Peeta as a more desirable partner for Katniss because he is a "loyal lover who dreams of a quiet and private home life as the end goal of utopia and the reason for social change." ${ }^{54}$ Toward the end of Mockingjay, Katniss despairs, reflecting, "I no longer feel any allegiance to these monsters called human beings, despite being one myself. I think that Peeta was onto something about us destroying one another and letting some decent species take over." ${ }^{55}$ The group of three young women I interviewed following $T H G$ fan panel at Dragon Con favored Gale over Peeta, one remarking that she had a "boner" for him, explaining:

He's kind of the male Katniss, he's the least selfish person everyone's like "oh, but he wants to go off and fight this war!" . . . and well yeah, but because he's looking at the bigger picture he knows what's gonna happen if this rebellion comes about, things are gonna get better, he wants that for his family.... That's why I think I like him the best, he loves his siblings. He's like the Papa Bear. . . . I just like that he doesn't think about himself, which Peeta doesn't either, but I think there's just something about the class divide and Peeta having been on the merchant side and Gale being on the same side it makes it very different for their circumstances.

At katnissisoliveskinneddealwithit, commenter Churayl was livid, and put this in more explicitly ideological terms, decrying the ending of the third book because "communism as represented by District 13 was vilified. ... Gale was demonized for resisting violently and constructed as morally wrong and inferior. ... Katniss was purged of revolutionary consciousness. ${ }^{.56}$ Academic feminist critics also see the conclusion as a betrayal of the strong feminist character 
portrayed in the first two books. ${ }^{57}$ Conservatives also stuck with Team Gale but describe him as behaving logically in a military context. At Goodreads, in a forum set up to combat the idea that Gale is a "villain," one reader fumed: "He made the bombs to help win a war, you fucking idiot. Maybe we should start dropping jelly beans on people that are trying to kill us." Two gun-rights advocates joined in, ridiculing members of Team Peeta for doing the equivalent of blaming "Gatling" for murders committed with guns he designed. ${ }^{58}$ Advocacy of revolution for these fans might appear in a strong right-wing populist armed attack on the federal government, more likely to support the man who showed up with a shotgun at a Washington, DC, pizzeria hoping to stop a governmentrun child sex ring than to view the Rojava resistance as heroic.

$T H G$ has been a vehicle for people to debate the ethics of war, the importance of vigilance in the name of democracy, the reality of class divisions and U.S. imperial power, and the impact of sadistic entertainment in our media culture. Yet criticisms of neoliberal society are not unique to the left, liberals, or progressives. These conflicting readings result from the vagueness of national appeals to the people, shared in various popular fictions, when brought into contact with efforts to respond to real-world economic inequality. This neoliberal populism appeals to readers across the political spectrum so that the same series is for one group a transparent allegory of an interracial class war against capitalism, for another a parable of white rural rebellion against a decadent globalist cultural elite, and for a third, and less visible, group of readers a global call to arms against the U.S. empire. Beyond the simple understanding that readers take different meanings from texts, or that authorial intention does not control the "real meaning," these diverse readings are indicative of the impact of populism's reduction of materialist discourses to a story of good people and bad government - and how this narrative fits into longer geographic rendering of class conflict in the United States. This seemingly unifying tale can cover many rifts, leaving us all in the position of Katniss standing in the arena, where it can be surprisingly difficult to distinguish between friends and foes.

\section{Appendix: Interview Questions}

\section{The Hunger Games Interview Questions-First Interview}

1. Would you describe yourself as a fan of The Hunger Games (THG)? If no, skip question 2.

2. What makes you a fan?

3. If not a fan, what is your relationship to the movie and or book?

4. What do you like most, the movie or the books?

5. How many times have you seen the movie? How many times have you read the books? 


\section{Rebecca Hill}

6. What do you like about $T H G$ ?

7. Do you see $T H G$ as having a message for people of today beyond being for entertainment?

8. If yes, what is that message?

9. Do you watch reality television? If yes, why? If no, why not?

10. What do you think $T H G$ is saying about reality television? Do you agree with the books or movie on this?

11. Do politics and debates about current events interest you? Why or why not?

12. Do you think that the message of $T H G$ is connected to a political party or political movement? If so, what? If not, why not?

13. Do you think that $T H G$ is trying to warn Americans about a particular political party or movement? If so, what? If not, why not?

14. How do you think that Panem (the country depicted in $T H G$ ) got to be the way it is before the events in the movie or books happened?

15. What do you think the most serious problems facing us as a society are?

16. Is it really possible that America is on the way to being like the society presented in $T H G$ ?

17. What could prevent that future from happening?

18. What are the main characteristics that you see in Katniss as a hero? What makes her so heroic?

19. What other characters do you think are important in the story?

20. Who are your favorite characters in $T H G$, and what do you like about them?

21. If you read the books before seeing the movie, what race did you imagine the characters were?

22. Do you think it makes a difference what race the characters are? Why or why not?

23. How did you feel about the race of characters chosen for the movie?

24. Do you go to $T H G$ fan sites? If yes, which ones?

25. If you answered "yes" to question 24, what do you like about $T H G$ fan sites?

26. What makes President Snow evil?

27. Why does Katniss kill President Coin? (only if they read book 3) 
28. What do you think the author is saying with the book's ending?

29. What else would you like to tell me about $T H G$ ?

\section{The Hunger Games Follow-up Interview after the Release of the Second Movie, Catching Fire}

1. Did you read the book Catching Fire? If no, skip to question 3.

2. Did you like the movie or the book more? Why?

3. Did you like the movie more or less than the first one? Why?

4. What did you think of the choices of actors to play Betee, Finnick, and Mags?

5. What do you think about Katniss's actions in the movie? Did she make good choices?

6. What do you think about the rebellion? Is it a good idea?

7. What is the difference between Gale and Peeta in this movie?

8. Who do you think Katniss should choose (Peeta or Gale) and why?

9. What were the best and worst parts of the movie?

10. What else would you like to tell me about the movie Catching Fire?

Final Films-The Hunger Games Interview Questions Following Mockingjay $1 \& 2$

1. Did you like the last two movies?

2. What were you most surprised by, if anything, in the last two movies?

3. Were you satisfied with what happened in the end?

4. Did it matter to you whether Katniss chose Gale or Peeta?

5. (if it didn't) What mattered most to you about the movies? What did you want to see them do?

6. What did you think the filmmakers were trying to say, if anything, with the way that the movies concluded?

7. Did you think the movies were very different from the books? If so, how?

8. Which did you like better, the movies or the books? Why?

9. Having now seen all the movies, if you were going to sum up in a couple of sentences what $T H G$ can teach us about politics, what would you say? 


\section{Notes}

1. A big thank you to graduate assistants Stephanie Craven, Nilufer Gokmen, and Lynne Tipton for their work on interviews and transcriptions for this project in 2014 and 2015 and particularly to Stephanie for her help in summer 2016 with revision and copyediting. I am also grateful for comments from my husband, Warner Belanger, and friends Nihad Farooq, Glenn Hendler, Joe Lowndes, Andrea Morrell, and Patricia Ventura and for supportive comments from the audience at The Society for Utopian Studies conference in Charleston, where I presented an earlier version of this paper in November 2013.

2. For a recent example, listen to "Killer Mike," being interviewed by W. Kamau Bell, as he describes his simultaneous support for Bernie Sanders, as a member of a union household, and his continuing belief in black capitalism, as derived through a personal history influenced by the Nation of Islam.

3. In Reading the Romance, Radway finds a small network of romance readers and interviews them about their favorite examples of romance to understand the pleasures they take from the genre. Janice Radway, Reading the Romance: Women, Patriarchy and Popular Literature (Chapel Hill: University of North Carolina Press, 1981).

4. Diane Roback, "Facts and Figures: Hunger Games Still Rules in Children's," Publisher's Weekly, March 17, 2013, accessed December 27, 2015; "All Time Box Office Adjusted for Ticket Price Inflation,” Box Office Mojo, n.d., accessed July 20, 2016.

5. "Best Dystopian and Post-Apocalyptic Fiction," Goodreads, n.d., accessed August 3, 2017, https://www.goodreads.com. On August 3, THG surpassed no. 2 ranked 1984 by more than 200,000 votes.

6. Kenneth Roemer, "Placing Readers in the Forefront of Nowhere: Reception Studies in Utopian Literature," in New Directions in American Reception Study, eds. Philip Goldstein and James L. Machor (New York: Oxford University Press, 2008), 108-9; see also Elizabeth Gurley Flynn, "Rebel Girl," 47; Bryan Palmer on James Cannon, 42; and Franklin Rosemont, "Bellamy's Radicalism Reclaimed," in Looking Backward, 1888-1988: Essays on Edward Bellamy, ed. Daphne Patai (Amherst: University of Massachusetts Press, 1988).

7. Carrie Hintz and Elaine Ostry, Utopian and Dystopian Writing for Children and Young Adults (New York: Routledge, 2013), 2.

8. Jeremy Scahill, "We Are All in Trump's Hunger Games Now," February 15, 2017, accessed April 7, 2017, https://theintercept.com/2017/02/15/intercepted-podcast-we-are-all-intrumps-hunger-games-now/

9. Tom Moylan and Rafaella Baccolini, Dark Horizons: Science Fiction and the Dystopian Imagination (New York: Routledge, 2013), 115.

10. John Fiske, "Television: Polysemy and Popularity," Critical Studies in Mass Communication 3, no. 4 (1986): 391-408.

11. Holloway cited in Stacy Takacs, Terrorism TV: Popular Entertainment in Post 9/11 America (Lawrence: University Press of Kansas, 2012), 92.

12. Suzanne Collins, The Hunger Games (New York: Scholastic, 2008).

13. Catching Fire (New York: Scholastic, 2009).

14. Mockingjay (New York: Scholastic 2010).

15. Susan Dominus, "Suzanne Collins's War Stories for Kids," New York Times, April 8, 2011, accessed August 4, 2016, http://www.nytimes.com.

16. Hannah Trierweiler Hudson, "Q \& A With Hunger Games Author Suzanne Collins," accessed August 5, 2016, http://www.scholastic.com.

17. Donald Sutherland, "Comments in Bonus Features." The Hunger Games, Lionsgate Films, 2012, film.

18. Seth Mydans, “Thai Protesters Are Detained after Using 'Hunger Games' Salute,” New York Times, 2014, accessed January 10, 2015; “Thailand: Anti-Coup Protests Use 'Hunger Games Gesture," News From Elsewhere, BBC News blogs, 2014, accessed August 5, 2016.

19. Matthew Jacobson, "Where We Stand: U.S. Empire at Street Level and in the Archive," American Quarterly, 65, no. 2 (2013): 265-90 and 274-75.

20. Ewan Morrison, "YA Dystopias Teach Children to Submit to the Free Market, Not Fight Authority," Guardian, 2014, accessed July 30, 2016.

21. Stella Morabito, "The Strange-Bedfellow Politics of 'The Hunger Games,"' Federalist, 2014, accessed June 27, 2016, http://thefederalist.com/. 2014).

22. Nicola Balkind, Fan Phenomena: The Hunger Games (University of Chicago Press,

23. Ben Murnane, "Now is Dystopia: Ayn Rand and the Right Wing Appropriation of the Hunger Games," Journal of Popular Culture v 51, n.2, 2018, pp. 280-301.

24. Dragon Con is a fan-run, SF/Fantasy convention held annually in Atlanta, GA and in 2013 was attended by over 60,000 people. The convention has a carnival-like atmosphere where it is common to socialize with strangers while waiting for panels to start or simply "hanging out." the Hunger Games movie had been out for a year, and the second was being widely promoted at 
the time, making it easy to approach people and ask "are you a fan of the Hunger Games?" I was most interested in those interviewees who identified as "fans" rather than as simply having read or enjoyed the series. Interview questions were designed to be legible to young people, to encourage "fannish" elaboration on favorite characters, and to ask fans to make explicit connections to real-world politics while not revealing the political views of the interviewer. In addition to approaching fans at Dragon Con, my graduate assistants and I also did interviews on the Kennesaw State University campus in 2014 and 2015 shortly following the releases of the 2nd, 3rd and 4th movies. Kennesaw is a suburban comprehensive university with over 30,000 undergraduates in the northwest suburbs of Atlanta. I interviewed one fan there. My assistant Lynne Tipton interviewed three fans by approaching students in the student center in Spring 2015. Stephanie Craven interviewed eight additional fans in fall 2015, both approaching them at the university, and recruiting people whom she already knew to be fans, through her own "geeky" social network. In this final group of interviews, the selection was less random, but because it was connected to a group whose primary relationship was already through "geek culture" fandom, and gaming, it was a relatively ideologically diverse group. Of the 24 total fans we interviewed, 20 were white, 15 were women; 2 identified as Latino; and 2 were African American. Most were in their early to mid-twenties, with the youngest fans interviewed being teenagers and the oldest in their mid-fifties. Most had read the books and seen the movies, often multiple times. All interviewees signed consent forms. Because some fans elected confidentiality and others did not, I refer to all subjects by first names only, in some cases with real first names and in some cases with pseudonyms. Demographic information about interviewees is mentioned briefly in the text of the paper. To balance the fan views for ideology, gender and idiosyncrasy of interpretation, I also evaluated online sources through a mixture of quantitative and qualitative measures: using widely popular social media sites which allow other readers to rank responses and reviews. I also sought explicitly ideological analyses through political websites where people had engaged in discussion about the series. When reviewing publications and reviews of the films and books, I read extensively through comment threads rather than relying only on the published articles.

25. Morrigan, comments on "The Hunger Games and National Socialism," Stormfront.org, 2014, accessed August 5, 2016, http://www.stormfront.org.

26. Stanley Fish, Is There a Text in This Class? The Authority of Interpretive Communities (Cambridge, MA: Harvard University Press, 1980).

27. On fan conflicts over SF literature awards, see Katy Waldman, "How Sci-Fi's Hugo Awards Got Their Own Full-Blown Gamergate," Slate.com, April 8, 2015, date August 3, 2017, http://www.slate.com/blogs/browbeat/2015/04/08/ 2015 hugo awards how the sad and rabid puppies_took_over_the_sci_fi_nominations.html.

28. Lawrence Goodwyn, The Populist Moment: A Short History of the Agrarian Revolt in America (New York: Oxford University Press, 1978); Chip Berlet and Matt Lyons, Right Wing Populism in America: Too Close for Comfort (Guilford Press, 2000): Cas Mudde and Cristóbal Rovira Kaltwasser, Populism: A Very Short Introduction (New York: Oxford University Press, 2017).

29. Charles Postel, The Populist Vision (New York: Oxford University Press, 2009).

30. Henry Nash Smith, The Virgin Land: The American West in Symbol and Myth (Cambridge, MA: Harvard University Press, 1950); Richard Slotkin, Regeneration through Violence: The Mythology of the American Frontier 1600-1860 (Norman: University of Oklahoma Press, 1973); Alexander Saxton, Rise and Fall of the White Republic: Class, Politics and Mass Culture in Nineteenth Century America (London: Verso, 1990).

31. Geoff Eley, "Fascism Then and Now," in Socialist Register, 2016: The Politics of the Right (London: Merlin Press, 2015), 105-6.

32. Raymond Williams, "Structures of Feeling," in Marxism and Literature (New York: Oxford University Press, 1977), 132-33.

33. Daniel Stedman-Jones, Masters of the Universe: Hayek, Friedman and the Birth of Neoliberal Politics (Princeton, NJ: Princeton University Press, 2012); David Harvey, A Brief History of Neoliberalism (New York: Oxford University Press, 2005).

34. Joseph Lowndes, "From Founding Violence to Political Hegemony: The Conservative Populism of George Wallace," in Populism and the Mirror of Democracy, ed. Francisco Panizza (New York: Verso, 2005), 144-71.

35. jlbishop comment on Kim Klimas, "Liberal or Conservative? Both Sides Trying to Claim 'Hunger Games' as Their Own-Why?’ TheBlaze.com, 2012, accessed July 31, 2016, http://www. theblaze.com.

36. Collins, Hunger Games, 18.

37. On the left discussion of Trump and the coming Reichstag fire, see Timothy Snyder, On Tyranny: Twenty Lessons from the Twentieth Century (Duggan Books, 2017); on Wallace, see Lowndes, "From Founding Violence,"; and on right-wing conspiracies about the deep state, see Rosie Gray, "An NSC Staffer Is Forced Out over a Controversial Memo," The Atlantic, 2 August 2017, https:/www.theatlantic.com/politics/archive/2017/08/a-national-security-council-staffer-isforced-out-over-a-controversial-memo/535725/. 


\section{Rebecca Hill}

38. Tom Moylan, Scraps of the Untainted Sky: Science Fiction, Utopia, Dystopia (Boulder, CO: Westview, 2000), 151. By hegemony here, I refer to a broad acceptance across class status and partisan identifications with free-market neoliberal ideology, described by theorist Antonio Gramsci as "the general direction imposed on social life by the dominant fundamental group" not so much through direct pressure or ideological instruction, but through "private enterprise" to the extent that ideology becomes "common sense" which may appear even in what are nominally "spontaneous" political actions. Gramsci, Selections from the Prison Notebooks of Antonio Gramsci, New York; International Publishers, 1971, p.12, 196-9

39. GraceG, "Comments on 'The Hunger Games' and Bread and Circuses," FreeRepublic. com, 2012, accessed August 4, 2016, http://freerepublic.com.

40. Alex Jones, "Deep Secrets of The Hunger Games Exposed," InfoWars.com, 2012, accessed 7 April 2017, https://www.infowars.com/deep-secrets-of-the-hunger-games-exposed/.

41. Veronica Roth, Divergent Trilogy (New York: Katherine Tegan Books, 2012-2013); Lauren Oliver, Delirium (New York: Harper Collins, 2011); Madeline L'Engle, A Wrinkle in Time (New York: Farrar, Straus and Giroux, 1963); Lois Lowry, The Giver, 1995.

42. Lisa, "Is the Hunger Games Capitol Communist?" Goodreads.com, March 11, 2013 August 1, 2016, accessed August 3, 2017, https://www.goodreads.com/topic/show/1246126-is-thehunger-games-capitol-communist.

43. Collins, Hunger Games, 8.

44. $\stackrel{\text {. }}{\longrightarrow} 282$.

45. Balkind, The Hunger Games; see also Sarah Seltzer, "The Imminent White-Washing of the Hunger Games Heroine," Jezebel, March 14, 2011, accessed August 3, 2017, http://jezebel. com/5781682/the-imminent-whitewashing-of-the-hunger-games-heroine.

46. Xalexiel Xalexiel, "Why Katniss Everdeen Is a Woman of Color," Xalexiel.Blogspot. com, 2011, accessed November 12, 2013, blog no longer available.

47. Hungergamestweets, Hungergamestweets.tumblr.com, n.d., accessed August 5, 2016 , http://www.tumblr.com.

48. Guy Kibbee, comment on Paul Bond, "The Politics of the Hunger Games," Hollywood Reporter, March 23, 2012, accessed August 5, 2016.

49. Tim Stanley, "Why Left and Right Both Love the Hunger Games," Daily Telegraph online, 2015, accessed April 8, 2017, http://www.telegraph.co.uk/film/the-hunger-games-mockingjay-part-2/politics-protests-katniss-suzanne-collins/.

50. Slotkin, Regeneration; Saxton, Rise and Fall.

51. A.R. Bovey, "Unexpected Direction, but Perfection (Potential Spoilers, but Pretty Vague)," reader review of Mockingjay, Amazon.com, 2010, accessed August 5, 2016, http://www. amazon.com.

52. BMW, "Cheated, Disappointed and Betrayed," reader review of Mockingjay, Amazon. com, September 1, 2010, accessed August 5, 2016, http://www.amazon.com.

53. Khan, (The Grinch). "What the Fuck Kind of Ending Is That!?" Goodreads.com, accessed July 20, 2016, https://www.goodreads.com.

54. Katherine R. Broad, "The Dandelion in the Spring: Utopia as Romance in Suzanne Collins's The Hunger Games Trilogy," in Contemporary Dystopian Fiction for Young Adults: Brave New Teenagers, ed. Carrie Hintz, Balaka Basu, and Katherine R. Broad (New York: Routledge, 2013), 120.

55. Collins, Mockingjay, 376.

56. Churayl, Katnissisoliveskinneddealwithit.tumblr.com, n.d., accessed 20 July 2016, http:// www.tumblr.com.

57. Antje M. Rauwerda, "Katniss, Military Bratness: Military Culture in Suzanne Collins' Hunger Games Trilogy," Children's Literature 44 (2016), 172-91.

58. "Why Does Everyone Say Gale Is a Villain!!!!?” Mockingjay discussions, Goodreads. com, comments from 2013-2016, accessed August 5, 2016, https://www.goodreads.com. 